\title{
Produktivitas Karkas Kelinci Hyla, Hycole dan New Zealand White
}

\author{
(Carcass Productivity of Hyla, Hycole and New Zealand White Rabbits) \\ Brahmantiyo $\mathrm{B}^{1}$, Nuraini $\mathrm{H}^{2}$, Rahmadiansyah $\mathrm{D}^{2}$ \\ ${ }^{1}$ Balai Pengkajian Teknologi Pertanian Maluku Utara \\ Kompleks Pertanian Kusu No. 1, Kota Tidore Kepulauan \\ ${ }^{2}$ Fakultas Peternakan, IPB, Jl. Agathis, Kampus IPB Darmaga 16680 \\ brahmantiyo@gmail.com
}

\begin{abstract}
The Hyla Rabbit from China and the Hycole rabbit from France are broiler rabbit imported in 2012 to be developed in Indonesia. The study was to evaluate the carcass productivity of imported rabbit compared with New Zealand White rabbits that have adapted in Indonesia. The animals used in study was five heads of each breeds, there were Hyla (CC), Hycole (PP) and New Zealand White (NN) rabbits. The observed variables are carcass characteristics (carcass weight, commercial cut and percentage) and non-carcass (non carcass part and percentage). The treatment effects were analyzed using covariate analysis with slaughter weights as covariate. The study showed that slaughter weight, carcass weight and percentage of rabbit carcasses of CC, PP and NN genotypes are no different. The difference is in commercial cut of rack of NN rabbit weights $(206.71 \pm 3.80 \mathrm{~g})$ higher than CC $(196.45 \pm 3.93 \mathrm{~g})$ and PP $(189.63 \pm 3.90 \mathrm{~g})$. The rabbit bone meat ratio of the three rabbits did not differ, they were $5.96 \pm 0.14(\mathrm{CC}), 5.82 \pm 0.14(\mathrm{PP})$ and $5.84 \pm 0.14(\mathrm{NN})$, respectively. The percentage of total fat was different, $6.01 \pm 0.25 \%$ (CC), $5.16 \pm 0.24 \%$ (PP) and $5.00 \pm 0.24 \%$ $(\mathrm{NN})$. The results showed that the productivity of $\mathrm{CC}$ and PP rabbit carcasses is better compared to NN and can be further developed into broiler rabbit and or through breeding program, by crossing or selection into broiler rabbits that are adaptive to tropical climate.
\end{abstract}

Key Words: Hyla, Hycole, New Zealand White, Carcass Characteristic

\begin{abstract}
ABSTRAK
Kelinci Hyla yang berasal dari Tiongkok dan kelinci Hycole berasal dari Perancis adalah kelinci pedaging yang diimpor pada tahun 2012 untuk dikembangkan di Indonesia. Tujuan dari penelitian ini adalah untuk mengevaluasi produktivitas karkasnya dibandingkan dengan kelinci New Zealand White yang telah beradaptasi di Indonesia untuk mengetahui performanya di iklim tropis Indonesia. Penelitian ini menggunakan kelinci jantan Hyla (CC), Hycole (PP) dan New Zealand White (NN) masing-masing berjumlah lima ekor. Peubah yang diamati adalah karakteristik karkas (bobot karkas, potongan komersial dan persentasenya) dan non-karkas (bagian non karkas dan persentasenya). Pengaruh perlakukan dianalisis menggunakan analisis kovariat dengan bobot potong sebagai kovariatnya. Bobot potong, bobot karkas dan persentase karkas kelinci CC, PP dan NN tidak berbeda. Perbedaan terdapat pada potongan komersial rack dengan bobot rack kelinci NN $(206,71 \pm 3,80 \mathrm{~g})$ lebih tinggi dibandingkan dengan kelinci CC $(196,45 \pm 3,93 \mathrm{~g})$ dan kelinci PP $(189,63 \pm 3,90 \mathrm{~g})$. Rasio daging tulang ketiga rumpun kelinci tidak berbeda, berturut-turut sebesar $5,96 \pm 0,14(\mathrm{CC}), 5,82 \pm 0,14(\mathrm{PP})$ dan 5,84 $\pm 0,14(\mathrm{NN})$. Persentase lemak total berbeda, masingmasing sebesar $6,01 \pm 0,25 \%$ pada kelinci CC, $5,16 \pm 0,24 \%$ pada kelinci PP dan 5,00 $\pm 0,24 \%$ pada kelinci NN. Hasil penelitian memperlihatkan bahwa produktivitas karkas kelinci CC dan PP sangat baik dan dapat dikembangkan lebih lanjut menjadi kelinci pedaging dan/atau melalui tindakan pemuliaan, baik persilangan maupun seleksi menjadi kelinci pedaging yang adaptif iklim tropis.
\end{abstract}

Kata Kunci: Hyla, Hycole, New Zealand White, Karakteristik Karkas 


\section{PENDAHULUAN}

Kelinci merupakan ternak yang memiliki potensi tinggi sebagai hewan peliharaan atau hias, penghasil daging maupun kulit-rambut (Raharjo et al. 2001). Peternakan kelinci di Indonesia sudah cukup memasyarakat sebab pemeliharaannya mudah, relatif tidak membutuhkan modal besar, siklus usaha relatif cepat, menghasilkan beragam produk, belum banyak pesaing, dapat memanfaatkan lahan sempit serta dapat memanfaatkan limbah pertanian sebagai pakan (Priyatna 2011). Pengembangan kelinci mempunyai prospek cukup baik dalam menanggulangi masalah kekurangan daging sebagai sumber protein secara terus menerus guna menjamin ketersediaan pangan di tingkat masyarakat (Farrell \& Raharjo 1984). Berdasarkan data statistik yang dilaporkan Ditjen PKH (2015), dari total produksi daging nasional sebesar 2,98 juta ton, sumbangsih daging kelinci hanya sebesar 554 ton $(0,019 \%)$. Apabila dilihat dari data tersebut, maka perlu adanya peningkatan terhadap pengembangan ternak kelinci pedaging sebagai alternatif pangan yang mampu membantu memenuhi kebutuhan daging bagi masyarakat.

Kelinci sebagai ternak pedaging memiliki beberapa keunggulan di antaranya yaitu daya reproduksi tinggi dengan pertumbuhan yang cepat. Kelinci Hyla dan Hycole merupakan rumpun kelinci dengan potensi sebagai pedaging unggul yang baru dikembangkan di Indonesia karena kemampuan pertumbuhan cepat dan produktivitas tinggi. Kelinci Hyla dan Hycole jantan mampu mencapai bobot tubuh $2160 \mathrm{~g}$ dan $2550 \mathrm{~g}$ pada umur 70 hari (Nizza \& Moniello 2000; Grimaud 2012). Pertumbuhan kelinci New Zealand White yaitu 1.990 g pada umur 70 hari (Hernandez \& Rubio 2001) tidak sebaik kelinci Hyla dan Hycole, namun sudah adaptif terhadap lingkungan tropis di Indonesia. Mengingat Indonesia merupakan negara tropis memiliki suhu dan kelembaban relatif tinggi yang dapat memengaruhi produktivitas kelinci. Sehubungan dengan itu diperlukan penelitian lebih dalam melalui uji karakteristik karkas terhadap kelinci Hyla dan Hycole sebagai penelitian eksplorasi untuk menguji potensi sebagai ternak penghasil daging unggul baru di Indonesia. Penelitian ini bertujuan untuk membandingkan pengaruh perbedaan rumpun kelinci Hyla, Hycole dan New Zealand White terhadap karakteristik karkas.

\section{MATERI DAN METODE}

Penelitian dilaksanakan di Kandang Kelinci, Balai Penelitian Ternak dan Laboratorium Ilmu Produksi Ternak Ruminansia Besar, Fakultas Peternakan, Institut Pertanian Bogor pada bulan Februari sampai Mei 2016. Materi yang digunakan pada penelitian adalah kelinci jantan Hyla (CC), Hycole (PP) dan New Zealand White (NN), masing-masing berjumlah lima ekor dan berumur 90 hari.

Kelinci dipelihara pada kandang individu yang dilengkapi dengan tempat pakan, water nipple dan bedding plastik. Kelinci dipelihara dengan pemberian pakan konsentrat (protein 17,8\% dan energi $4.098 \mathrm{kkal}$ ) sebanyak $100 \mathrm{~g} / \mathrm{ekor} / \mathrm{hari}$ dan air minum secara ad libitum. Kelinci juga diberikan hijauan berupa daun pohpohan (Trichanthera gigantia) dan rumput gajah (Pennisetum purpureum) sebanyak $100 \mathrm{~g} / \mathrm{ekor} / \mathrm{hari}$.

Sebelum pemotongan, kelinci dipuasakan selama 16 jam, namun air tetap tersedia dan ditimbang untuk mendapatkan bobot potong. Kelinci disembelih dengan cara memotong tiga saluran yaitu esophagus, trakhea dan dua pembuluh darah arteri carotis dan vena jugularis, sehingga proses pengeluaran darah berlangsung sempurna. Darah yang keluar ditampung dan ditimbang.

Setelah proses pemotongan, dibuat irisan pada kulit antara tulang dan tendo sendi salah satu kaki belakang lalu digantung menggunakan hook. Kepala dipisahkan dari tubuh 
pada sendi occipito atlantis serta kaki depan dan kaki belakang dipotong pada sendi sikunya, masing-masing ditimbang. Selanjutnya, ekor dipotong dari pangkalnya, lalu kelinci dikuliti serta isi rongga perut dan dada dikeluarkan (evisceration). Bagian kulitrambut, saluran pencernaan, hati, jantung, ginjal, paru-paru masing-masing ditimbang. Karkas kemudian dibersihkan dengan air bersih dan dilayukan (chilling) dalam refrigerator pada suhu $\pm 4^{\circ} \mathrm{C}$ selama 24 jam.

Karkas yang sudah dilayukan kemudian diuraikan menjadi empat bagian potongan komersial berdasarkan metode Blasco et al. (1993), yaitu kaki depan (foreleg), rusuk dada (rack), pinggang (loin) dan kaki belakang (hindleg). Potongan foreleg dipotong mulai dari leher hingga antara tulang rusuk ketujuh dan kedelapan. Potongan rack dipotong mulai dari antara tulang rusuk ketujuh dan kedelapan hingga rusuk terakhir.

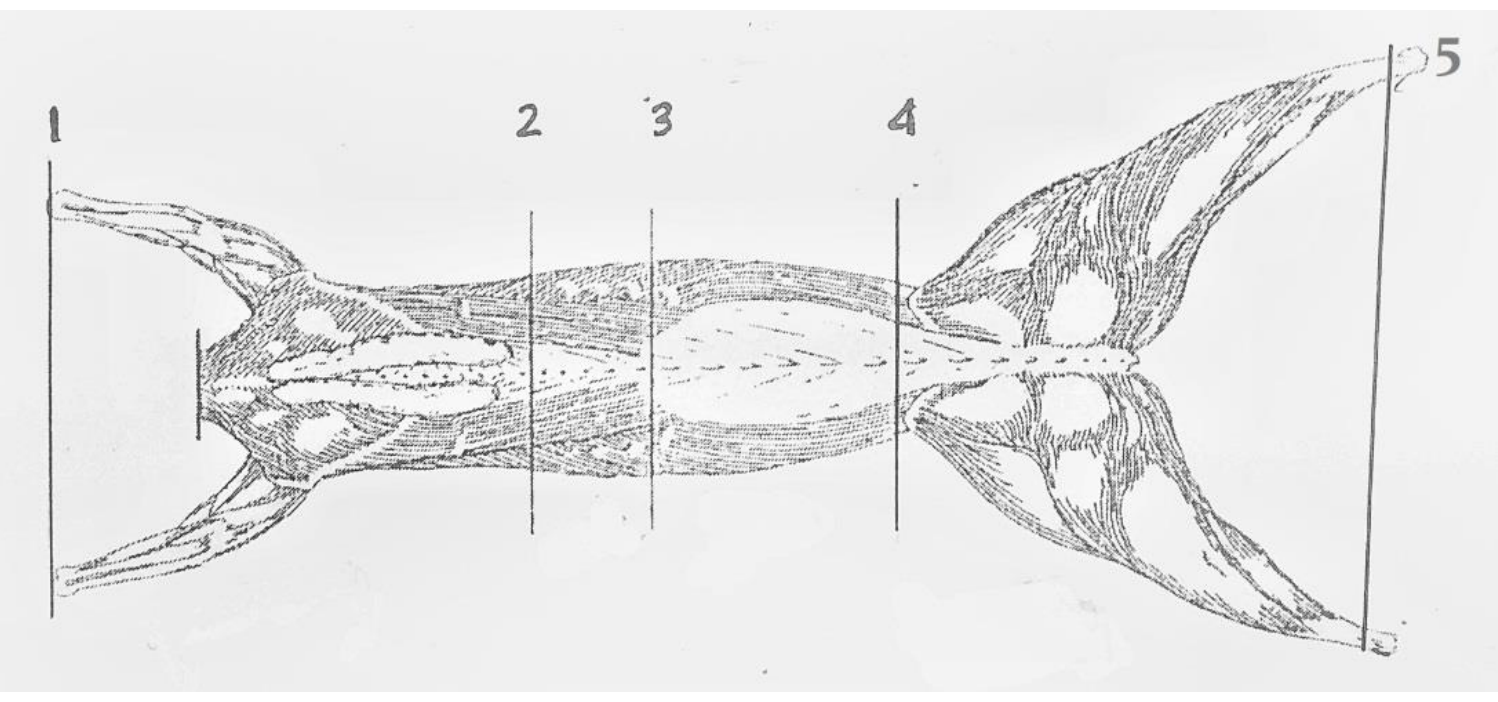

Gambar 1. Potongan komersial karkas kelinci, 1-2: Foreleg, 2-3: Rack, 3-4: Loin dan 4-5: Hindleg

Sumber: Blasco et al. (1993)

Bagian loin dipotong mulai dari rusuk terakhir hingga antara lumbar vertebra keenam dan ketujuh di mana pemotongan di area tersebut dilakukan lurus ke sisi karkas. Potongan hindleg dipotong mulai dari lumbar vertebra keenam dan ketujuh hingga pangkal ekor (os coxae). Setiap bagian potongan karkas ditimbang lalu dilakukan pemisahan daging, tulang (deboning) dan lemak (subkutan, abdomen, pelvis, intermuskular dan ginjal) dari setiap bagian potongan karkas tersebut, masing-masing ditimbang terpisah.

Penelitian ini menggunakan rancangan acak lengkap (RAL) yang terdiri atas tiga rumpun kelinci (Hyla, Hycole dan New Zealand White) dengan ulangan lima ekor. Data yang diperoleh dianalisis menggunakan analysis of covarience (ANCOVA). Bobot awal digunakan sebagai kovariat. Bila terdapat perbedaan nyata pada data, maka akan diuji lanjut menggunakan Uji Least Squares Means.

Peubah yang diamati meliputi bobot potong, bobot karkas (Soeparno 1991), persentase bobot karkas, bobot komponen karkas (bobot daging dan bobot tulang foreleg, rack, loin dan hindleg menurut Blasco (1993), lemak (subkutan, abdomen, pelvis, intermuskular dan ginjal), persentase bobot komponen karkas, dan rasio daging: tulang, serta bobot dan persentase komponen non-karkas (kepala, kaki depan dan belakang, kulitrambut, saluran pencernaan, hati, jantung, ginjal, paru-paru dan darah). 


\section{HASIL DAN PEMBAHASAN}

\section{Bobot potong, bobot karkas dan persentase karkas}

Karkas kelinci memiliki definisi yaitu bagian dari tubuh ternak kelinci setelah dipotong, dikurangi darah, kepala, kulit, kaki, ekor, saluran pencernaan beserta isinya dan isi rongga dada. Karakteristik karkas yang diamati adalah bobot potong serta bobot dan persentase karkas, potongan komersial, komponen karkas dan non-karkas. Hasil analisis nilai rata-rata bobot potong, bobot karkas dan persentase karkas kelinci Hyla (CC), Hycole (PP) dan New Zealand White (NN) disajikan pada Tabel 1.

Tabel 1. Rata-rata bobot potong, bobot karkas dan persentase karkas kelinci

\begin{tabular}{lccc}
\hline \hline \multirow{2}{*}{ Karakteristik bobot karkas } & \multicolumn{3}{c}{ Rumpun } \\
\cline { 2 - 4 } & $\mathrm{CC}$ & $\mathrm{PP}$ & $\mathrm{NN}$ \\
\hline Bobot potong $(\mathrm{g})$ & $3.015,53 \pm 63,48^{\mathrm{a}}$ & $3.118,09 \pm 64,72^{\mathrm{a}}$ & $3.133,33 \pm 64,61^{\mathrm{a}}$ \\
Bobot karkas (g) & $1.692,81 \pm 17,07^{\mathrm{a}}$ & $1.681,29 \pm 16,91^{\mathrm{a}}$ & $1.685,41 \pm 16,48^{\mathrm{a}}$ \\
Persentase karkas (\%) & $55,14 \pm 0,46^{\mathrm{a}}$ & $54,80 \pm 0,46^{\mathrm{a}}$ & $55,80 \pm 0,45^{\mathrm{a}}$ \\
\hline
\end{tabular}

Superskrip berbeda pada baris yang sama, berbeda nyata $(\mathrm{P}<0,05)$; $\mathrm{CC}$ : Hyla; PP: Hycole: NN: New Zealand White

Hasil analisis menunjukkan tidak adanya pengaruh perbedaan $(\mathrm{P}>0,05)$ rumpun kelinci terhadap peubah bobot potong, bobot karkas dan persentase karkas. Hal ini menggambarkan bahwa kelinci impor (CC dan PP) memiliki laju pertumbuhan yang sama dengan kelinci NN pada kondisi pakan dan pengelolaan yang diberikan. Bobot potong dan bobot karkas sangat dipengaruhi oleh umur, jenis dan pakan. Bobot potong dan bobot karkas dari ketiga kelinci (CC, PP dan NN) tidak menunjukkan perbedaan dengan kisaran umur fisiologis dan pemberian kualitas pakan yang sama. Hal ini menunjukkan bahwa bobot potong yang tidak berbeda menghasilkan bobot dan persentase karkas yang tidak berbeda pula. Brahmantiyo et al. (2010) menyatakan bahwa semakin tinggi bobot potong semakin tinggi bobot karkasnya, begitu pun sebaliknya. Ditambahkan bahwa produksi karkas yang dicerminkan dengan perdagingan, perlemakan, dan pertulangan kelinci terlihat sangat dipengaruhi oleh bobot potongnya.

Hasil perhitungan persentase karkas sejalan dengan hasil pengukuran terhadap bobot potong dan karkas karena persentase karkas merupakan perbandingan antara bobot karkas dengan bobot potong dikali dengan 100\% (Santoso 2010). Diperoleh persentase karkas sama dengan hasil penelitian Ozimba \& Lukefahr (1991) yang memperoleh rataan persentase karkas sebesar 55\% pada kelinci NZW, California dan Persilangan NZW ×California. Ouyed \& Brun (2008) juga memperoleh rataan persentase karkas kelinci Californian, New Zealand dan persilangan timbal baliknya (NZ×CA dan CA $\times N Z$ ) berturut-turut sebesar 55,5; 53,5; 53,0; dan 53,8\%. Zita et al. (2012) menyatakan bahwa persentase karkas kelinci CC mampu mencapai 57,8\%, sedangkan kelinci PP 58,9\% (Metzger et al. 2004). Hasil tersebut lebih tinggi dibandingkan dengan hasil pada penelitian ini yang dapat disebabkan adanya pengaruh lingkungan serta interaksi genetik dengan lingkungannya seperti perbedaan iklim. Pengaruh lingkungan pada kelinci eksotik dilaporkan oleh Wang et al. (2016) yang mengevaluasi produktivitas kelinci impor (Hyla dan Champagne) dan lokal Tiongkok (Tainfu Black), diperoleh persentase kepala, kulit, saluran pencernaan dan karkas komersial kelinci Tianfu Black lebih tinggi $(\mathrm{P}<0,05)$ disbanding kelinci Hyla dan Champagne. 
Menurut Parwoto (1995), karkas sebagai satuan produksi yang bernilai ekonomi tinggi dan secara praktis dapat digunakan sebagai satuan produksi yang komposisi dan persentasenya dapat digunakan sebagai kriteria keberhasilan usaha ternak. Gillespie (2004) menyatakan bahwa persentase karkas yang baik yaitu sebesar $50-59 \%$. Nilai persentase karkas kelinci CC dan PP sama baiknya dengan kelinci NN yaitu sekitar 55\%. Sehingga, produksi karkas kelinci CC dan PP dapat dikatakan baik dan memiliki potensi sebagai kelinci pedaging unggul di Indonesia seperti kelinci NN.

\section{Potongan komersial karkas}

Pemotongan bagian karkas kelinci berdasarkan pada irisan komersial. Irisan komersial karkas kelinci terdiri atas empat potong irisan yaitu potongan irisan kaki depan (foreleg), potongan irisan dada (rack), potongan irisan pinggang (loin) dan potongan irisan kaki belakang (hindleg) (De Blass et al. 1977; Blasco et al. 1993). Berikut hasil analisis rataan bobot dan persentase potongan komersial karkas kelinci CC, PP dan NN yang disajikan pada Tabel 2.

Tabel 2. Rata-rata bobot dan persentase potongan komersial karkas kelinci

\begin{tabular}{lrrr}
\hline \hline \multirow{2}{*}{ Potongan komersial } & \multicolumn{3}{c}{ Rumpun } \\
\cline { 2 - 4 } & \multicolumn{1}{c}{$\mathrm{CC}$} & \multicolumn{1}{c}{ PP } & \multicolumn{1}{c}{$\mathrm{NN}$} \\
\hline Bobot foreleg $(\mathrm{g})$ & $475,01 \pm 7,55^{\mathrm{a}}$ & $463,93 \pm 7,48^{\mathrm{a}}$ & $459,38 \pm 7,29^{\mathrm{a}}$ \\
Persentase foreleg (\%) & $28,08 \pm 0,33^{\mathrm{a}}$ & $27,61 \pm 0,33^{\mathrm{a}}$ & $27,27 \pm 0,32^{\mathrm{a}}$ \\
Bobot rack $(\mathrm{g})$ & $196,45 \pm 3,93^{\mathrm{ab}}$ & $189,63 \pm 3,90^{\mathrm{a}}$ & $206,71 \pm 3,80^{\mathrm{b}}$ \\
Persentase rack (\%) & $11,59 \pm 0,22^{\mathrm{ab}}$ & $11,29 \pm 0,22^{\mathrm{a}}$ & $12,26 \pm 0,21^{\mathrm{b}}$ \\
Bobot loin (g) & $378,24 \pm 8,50^{\mathrm{a}}$ & $372,41 \pm 8,42^{\mathrm{a}}$ & $361,74 \pm 8,21^{\mathrm{a}}$ \\
Persentase loin (\%) & $22,31 \pm 0,38^{\mathrm{a}}$ & $22,12 \pm 0,37^{\mathrm{a}}$ & $21,46 \pm 0,36^{\mathrm{a}}$ \\
Bobot hindleg (g) & $605,63 \pm 9,91^{\mathrm{a}}$ & $615,72 \pm 9,81^{\mathrm{a}}$ & $626,19 \pm 9,56^{\mathrm{a}}$ \\
Persentase hindleg (\%) & $35,79 \pm 0,51^{\mathrm{a}}$ & $36,65 \pm 0,51^{\mathrm{a}}$ & $37,16 \pm 0,50^{\mathrm{a}}$ \\
\hline
\end{tabular}

Superskrip yang berbeda pada baris yang sama, berbeda nyata $(\mathrm{P}<0.05)$; CC: Hyla; PP: Hycole; NN: New Zealand White

Potongan komersial merupakan potongan-potongan bagian karkas, sehingga semakin tinggi bobot karkas maka akan semakin tinggi pula potongan komersialnya. Hasil tersebut menunjukkan bahwa terdapat perbedaan pada bobot dan persentase rack antara kelinci PP dan NN, sedangkan dengan kelinci CC tidak berbeda. Kelinci NN memiliki bobot dan persentase rack yang lebih tinggi $(206,71 \pm 3,80 \mathrm{~g}$ dan $12,26 \pm 0,21 \%)$ dibandingkan kelinci PP $(189,63 \pm 3,90 \mathrm{~g}$ dan $11,29 \pm 0,22 \%)$. Hasil ini dapat disebabkan pertumbuhan yang tidak sama pada bagian rack dari kelinci PP dan NN karena dipengaruhi perbedaan ekspresi genetik masing-masing rumpun kelinci dan interaksi genetik dengan lingkungannya (Brahmantiyo \& Raharjo 2009).

Herman (1986) menyatakan bahwa hasil pengirisan pada potongan komersial menunjukkan persentase yang konsisten dengan koefisien keragaman yang rendah. Persentase irisan karkas terhadap bobot tubuh secara terinci menurut Herman (1986) yaitu irisan kaki depan (foreleg) $\pm 29 \%$, dada (rack) $\pm 11,68 \%$, pinggang (loin) $\pm 22,10 \%$ dan kaki belakang (hindleg) $\pm 40 \%$. Hasil tersebut tidak terpaut jauh dengan hasil yang didapat pada penelitian ini. Menurut Blasco et al. (1993), potongan komersial yang bernilai ekonomis tinggi (first retail cuts) dari kelinci adalah potongan bagian hindleg, loin dan foreleg 
sedangkan potongan rack adalah potongan dengan nilai ekonomis yang lebih rendah (second retail cuts). Sehingga evaluasi karkas berdasarkan persentase potongan komersialnya dapat memberikan gambaran hasil akhir secara ekonomis (Brahmantiyo \& Raharjo 2009).

\section{Komponen karkas}

Komponen karkas terdiri atas tiga jaringan utama yaitu tulang, daging dan lemak (Soeparno 1992). Hasil analisis komponen-komponen karkas kelinci CC, PP dan NN disajikan pada Tabel 3. Hasil tersebut menunjukkan bahwa adanya pengaruh rumpun terhadap beberapa peubah komponen karkas. Kelinci NN memiliki bobot dan persentase daging foreleg $(314,18 \pm 2,95 \mathrm{~g}$ dan $10,18 \pm 0,09 \%)$ serta daging loin $(303,99 \pm 5,57 \mathrm{~g}$ dan $9,87 \pm 0,19 \%)$ yang lebih tinggi dibandingkan dengan kelinci CC $(298,38 \pm 3,06 \mathrm{~g}$ dan $9,66 \pm 0,10 \%$ serta $277,36 \pm 5,77 \mathrm{~g}$ dan $8,96 \pm 0,19 \%$ ). Bobot dan persentase tulang rack kelinci CC $(26,34 \pm 0,45 \mathrm{~g}$ dan $0,85 \pm 0,01 \%)$ lebih tinggi dibandingkan dengan kelinci PP $(24,16 \pm 0,45 \mathrm{~g}$ dan $0,78 \pm 0,01 \%)$ dan $\mathrm{NN}(24,04 \pm 0,44 \mathrm{~g}$ dan $0,78 \pm 0,01 \%)$. Bobot dan persentase tulang loin kelinci $\mathrm{CC}(30,64 \pm 0,77 \mathrm{~g}$ dan $0,99 \pm 0,02 \%)$ lebih tinggi dibandingkan dengan kelinci PP $(26,82 \pm 0,76 \mathrm{~g}$ dan $0,87 \pm 0,02 \%)$. Bobot dan persentase tulang hindleg kelinci PP $(86,30 \pm 2,12 \mathrm{~g}$ dan $2,79 \pm 0,07 \%)$ dan $\mathrm{NN}(86,19 \pm 2,06 \mathrm{~g}$ dan $2,79 \pm 0,06 \%)$ lebih tinggi dibandingkan dengan kelinci CC $(77,62 \pm 2,14 \mathrm{~g}$ dan $2,50 \pm 0,07 \%$ ). Perbedaan ini diduga tidak dipengaruhi oleh bobot potongnya, namun disebabkan oleh variasi genetik tiap individu kelinci. Adanya pengaruh rumpun pada produktivitas karkas kelinci terdapat pada rumpun kelinci New Zealand White (NZW) dan Calfiornian (CAL) dengan persentase bobot karkas panas, bobot karkas panas ditambah giblet dan bobot karkas panas ditambah giblet dan kepala berturut-turut sebesar 48,0 dengan 47,2\%; 52,1 dengan 51,4\%; dan 58,5 dengan 57,3\% (Baiomy \& Hassanien 2011; Wang et al. 2016).

Jumlah daging dan tulang dari ketiga kelinci tidak memiliki perbedaan pada bobot maupun persentasenya, sehingga didapatkan rasio daging:tulang yang sama pula. Perkembangan tulang menentukan ukuran tubuh dan produksi daging seekor ternak dan diharapkan memiliki persentase sekecil mungkin. Basuki et al. (1981) menyatakan bahwa bobot potong kelinci yang diharapkan pada peternakan komersial yaitu 1,8-2,7 kg dengan produksi karkas 0,9-1,4 kg yang persentase karkasnya sebesar 55\% serta rasio daging dan tulang adalah 5:1. Ketiga rumpun kelinci yang diamati memiliki nilai rasio 5,82 $\pm 0,14$ sampai 5,96 $\pm 0,14$. Sehingga produksi daging kelinci CC, PP dan NN yang diamati masih tinggi dan sesuai dengan yang diharapkan peternakan komersial.

Distribusi lemak sangat memengaruhi persentase jaringan otot karkas sebab persentase daging dan tulang akan berkurang sedangkan komponen lemak bertambah dengan meningkatnya bobot karkas (Seebeck \& Tulloh 1968). Secara umum jika persentase lemak dalam karkas meningkat maka persentase tulang dan daging akan menurun (Tahir et al. 1994; Moron \& Clavero 1999). Berdasarkan hasil pada Tabel 3, kelinci CC memiliki bobot dan persentase lemak intermuskular $(42,57 \pm 2,73 \mathrm{~g}$ dan $1,37 \pm 0,08 \%)$ serta lemak ginjal $(10,69 \pm 0,58 \mathrm{~g}$ dan $0,34 \pm 0,02 \%)$ yang lebih tinggi dibandingkan dengan kelinci $\mathrm{NN}(31,17 \pm 2,63 \mathrm{~g}$ dan $1,00 \pm 0,08 \%$ serta $7,72 \pm 0,56 \mathrm{~g}$ dan $0,24 \pm 0,02 \%)$. Adapun total bobot dan persentase lemak dari kelinci CC $(185,80 \pm 7,84 \mathrm{~g}$ dan 6,01 $\pm 0,25 \%)$ lebih tinggi dibandingkan dengan kelinci $\mathrm{NN}(154,92 \pm 7,57 \mathrm{~g}$ dan $5,00 \pm 0,24 \%$ ). Brahmantiyo \& Raharjo (2009) menyatakan bahwa rumpun kelinci berpengaruh terhadap deposit lemak. 
Tabel 3. Rata-rata bobot dan persentase komponen karkas kelinci

\begin{tabular}{|c|c|c|c|}
\hline \multirow{2}{*}{ Komponen karkas } & \multicolumn{3}{|c|}{ Rumpun } \\
\hline & $\mathrm{CC}$ & PP & $\mathrm{NN}$ \\
\hline Bobot daging foreleg $(\mathrm{g})$ & $298,38 \pm 3,06^{\mathrm{a}}$ & $309,92 \pm 3,03^{\mathrm{ab}}$ & $314,18 \pm 2,95^{\mathrm{b}}$ \\
\hline Persentase daging foreleg (\%) & $9,66 \pm 0,10^{\mathrm{a}}$ & $10,03 \pm 0,10^{\mathrm{ab}}$ & $10,18 \pm 0,09^{b}$ \\
\hline Bobot daging rack (g) & $167,84 \pm 2,46^{\mathrm{a}}$ & $162,48 \pm 2,44^{\mathrm{a}}$ & $166,44 \pm 2,37^{\mathrm{a}}$ \\
\hline Persentase daging rack (\%) & $5,43 \pm 0,08^{a}$ & $5,25 \pm 0,08^{\mathrm{a}}$ & $5,38 \pm 0,08^{\mathrm{a}}$ \\
\hline Bobot daging loin $(\mathrm{g})$ & $277,36 \pm 5,77^{\mathrm{a}}$ & $292,67 \pm 5,72^{\mathrm{ab}}$ & $303,99 \pm 5,57^{\mathrm{b}}$ \\
\hline Persentase daging loin (\%) & $8,96 \pm 0,19^{\mathrm{a}}$ & $9,47 \pm 0,19^{\mathrm{ab}}$ & $9,87 \pm 0,19^{b}$ \\
\hline Bobot daging hindleg (g) & $514,10 \pm 11,30^{\mathrm{a}}$ & $498,80 \pm 11,19^{\mathrm{a}}$ & $494,22 \pm 10,91^{\mathrm{a}}$ \\
\hline Persentase daging hindleg (\%) & $16,63 \pm 0,36^{\mathrm{a}}$ & $16,15 \pm 0,36^{\mathrm{a}}$ & $16,03 \pm 0,35^{\mathrm{a}}$ \\
\hline Total bobot daging (g) & $1.257,68 \pm 13,03^{\mathrm{a}}$ & $1.263,88 \pm 12,91^{\mathrm{a}}$ & $1.278,83 \pm 12,58^{\mathrm{a}}$ \\
\hline Persentase total daging $(\%)$ & $40,68 \pm 0,44^{\mathrm{a}}$ & $40,91 \pm 0,43^{\mathrm{a}}$ & $41,46 \pm 0,42^{\mathrm{a}}$ \\
\hline Bobot tulang foreleg $(\mathrm{g})$ & $77,16 \pm 2,00^{\mathrm{a}}$ & $80,24 \pm 1,98^{\mathrm{a}}$ & $81,84 \pm 1,93^{\mathrm{a}}$ \\
\hline Persentase tulang foreleg (\%) & $2,50 \pm 0,06^{\mathrm{a}}$ & $2,59 \pm 0,06^{\mathrm{a}}$ & $2,65 \pm 0,06^{\mathrm{a}}$ \\
\hline Bobot tulang rack $(\mathrm{g})$ & $26,34 \pm 0,45^{\mathrm{b}}$ & $24,16 \pm 0,45^{\mathrm{a}}$ & $24,04 \pm 0,44^{\mathrm{a}}$ \\
\hline Persentase tulang rack (\%) & $0,85 \pm 0,01^{\mathrm{b}}$ & $0,78 \pm 0,01^{\mathrm{a}}$ & $0,78 \pm 0,01^{\mathrm{a}}$ \\
\hline Bobot tulang loin $(\mathrm{g})$ & $30,64 \pm 0,77^{\mathrm{b}}$ & $26,82 \pm 0,76^{\mathrm{a}}$ & $27,85 \pm 0,74^{\mathrm{ab}}$ \\
\hline Persentase tulang loin (\%) & $0,99 \pm 0,02^{\mathrm{b}}$ & $0,87 \pm 0,02^{\mathrm{a}}$ & $0,90 \pm 0 ., 2^{\mathrm{ab}}$ \\
\hline Bobot tulang hindleg $(\mathrm{g})$ & $77,62 \pm 2,14^{\mathrm{a}}$ & $86,30 \pm 2,12^{\mathrm{b}}$ & $86,19 \pm 2,06^{b}$ \\
\hline Persentase tulang hindleg (\%) & $2,50 \pm 0,07^{\mathrm{a}}$ & $2,79 \pm 0,07^{\mathrm{b}}$ & $2,79 \pm 0,06^{\mathrm{b}}$ \\
\hline Total bobot tulang $(\mathrm{g})$ & $211,76 \pm 4,25^{\mathrm{a}}$ & $217,53 \pm 4,21^{\mathrm{a}}$ & $219,92 \pm 4,10^{\mathrm{a}}$ \\
\hline Persentase total tulang $(\%)$ & $6,85 \pm 0,13^{\mathrm{a}}$ & $7,03 \pm 0,13^{\mathrm{a}}$ & $7,11 \pm 0,13^{\mathrm{a}}$ \\
\hline Rasio daging:tulang & $5,96 \pm 0,14^{\mathrm{a}}$ & $5,82 \pm 0,14^{\mathrm{a}}$ & $5,84 \pm 0,14^{\mathrm{a}}$ \\
\hline Bobot lemak subkutan (g) & $85,40 \pm 3,05^{\mathrm{a}}$ & $77,92 \pm 3,02^{\mathrm{a}}$ & $78,40 \pm 2,95^{\mathrm{a}}$ \\
\hline Persentase lemak subkutan (\%) & $2,76 \pm 0,10^{\mathrm{a}}$ & $2,52 \pm 0,10^{\mathrm{a}}$ & $2,54 \pm 0,10^{\mathrm{a}}$ \\
\hline Bobot lemak abdomen $(\mathrm{g})$ & $9,92 \pm 0,67^{\mathrm{a}}$ & $8,47 \pm 0,67^{\mathrm{a}}$ & $7,65 \pm 0,65^{\mathrm{a}}$ \\
\hline Persentase lemak abdomen (\%) & $0,32 \pm 0,02^{\mathrm{a}}$ & $0,27 \pm 0,02^{\mathrm{a}}$ & $0,24 \pm 0,02^{\mathrm{a}}$ \\
\hline Bobot lemak pelvis $(\mathrm{g})$ & $37,22 \pm 2,09^{\mathrm{a}}$ & $31,85 \pm 2,07^{\mathrm{a}}$ & $29,99 \pm 2,02^{\mathrm{a}}$ \\
\hline Persentase lemak pelvis (\%) & $1,20 \pm 0,07^{\mathrm{a}}$ & $1,02 \pm 0,06^{\mathrm{a}}$ & $0,96 \pm 0,06^{\mathrm{a}}$ \\
\hline Bobot lemak intermuskular (g) & $42,57 \pm 2,73^{b}$ & $32,59 \pm 2,70^{\mathrm{ab}}$ & $31,17 \pm 2,63^{\mathrm{a}}$ \\
\hline Persentase lemak intermuskular (\%) & $1,37 \pm 0,08^{\mathrm{b}}$ & $1,04 \pm 0,08^{\mathrm{ab}}$ & $1,00 \pm 0,08^{\mathrm{a}}$ \\
\hline Bobot lemak ginjal (g) & $10,69 \pm 0,58^{b}$ & $9,42 \pm 0,57^{\mathrm{ab}}$ & $7,72 \pm 0,56^{\mathrm{a}}$ \\
\hline Persentase lemak ginjal (\%) & $0,34 \pm 0,02^{\mathrm{b}}$ & $0,30 \pm 0,02^{\mathrm{ab}}$ & $0,24 \pm 0,02^{\mathrm{a}}$ \\
\hline Total bobot lemak (g) & $185,80 \pm 7,84^{\mathrm{b}}$ & $160,25 \pm 7,76^{\mathrm{ab}}$ & $154,92 \pm 7,57^{\mathrm{a}}$ \\
\hline Persentase total lemak (\%) & $6,01 \pm 0,25^{\mathrm{b}}$ & $5,16 \pm 0,24^{\mathrm{ab}}$ & $5,00 \pm 0,24^{\mathrm{a}}$ \\
\hline
\end{tabular}

Superskrip yang berbeda pada baris yang sama, beda nyata $(\mathrm{P}<0,05)$; CC: Hyla; PP: Hycole; NN: New Zealand White 


\section{Komponen non-karkas}

Bobot non-karkas merupakan bobot yang berasal dari bagian selain karkas. Berikut hasil analisis rata-rata bobot dan persentase komponen non karkas kelinci CC, PP dan NN yang disajikan pada Tabel 4 di bawah ini.

Tabel 4. Rata-rata bobot dan persentase komponen non-karkas kelinci

\begin{tabular}{lccc}
\hline \hline \multirow{2}{*}{ Komponen non-karkas } & \multicolumn{3}{c}{ Rumpun } \\
\cline { 2 - 4 } & $\mathrm{CC}$ & $\mathrm{PP}$ & $\mathrm{NN}$ \\
\hline Bobot jantung (g) & $9,52 \pm 0,62^{\mathrm{a}}$ & $9,98 \pm 0,61^{\mathrm{a}}$ & $9,25 \pm 0,60^{\mathrm{a}}$ \\
Persentase jantung (\%) & $0,31 \pm 0,02^{\mathrm{a}}$ & $0,33 \pm 0,02^{\mathrm{a}}$ & $0,30 \pm 0,02^{\mathrm{a}}$ \\
Bobot paru-paru (g) & $13,12 \pm 0,71^{\mathrm{a}}$ & $12,31 \pm 0,70^{\mathrm{a}}$ & $13,52 \pm 0,68^{\mathrm{a}}$ \\
Persentase paru-paru (\%) & $0,43 \pm 0,02^{\mathrm{a}}$ & $0,40 \pm 0,02^{\mathrm{a}}$ & $0,44 \pm 0,02^{\mathrm{a}}$ \\
Bobot ginjal (g) & $16,75 \pm 0,81^{\mathrm{a}}$ & $16,80 \pm 0,81^{\mathrm{a}}$ & $15,65 \pm 0,79^{\mathrm{a}}$ \\
Persentase ginjal (\%) & $0,54 \pm 0,03^{\mathrm{a}}$ & $0,54 \pm 0,03^{\mathrm{a}}$ & $0,51 \pm 0,02^{\mathrm{a}}$ \\
Bobot kaki depan (g) & $29,73 \pm 0,47^{\mathrm{b}}$ & $28,76 \pm 0,47^{\mathrm{ab}}$ & $27,86 \pm 0,45^{\mathrm{a}}$ \\
Persentase kaki depan (\%) & $0,96 \pm 0,02^{\mathrm{b}}$ & $0,93 \pm 0,01^{\mathrm{ab}}$ & $0,90 \pm 0,01^{\mathrm{a}}$ \\
Bobot kaki belakang (g) & $69,82 \pm 1,60^{\mathrm{a}}$ & $70,09 \pm 1,59^{\mathrm{a}}$ & $69,35 \pm 1,55^{\mathrm{a}}$ \\
Persentase kaki belakang (\%) & $2,26 \pm 0,05^{\mathrm{a}}$ & $2,27 \pm 0,05^{\mathrm{a}}$ & $2,25 \pm 0,05^{\mathrm{a}}$ \\
Bobot hati (g) & $74,00 \pm 1,16^{\mathrm{a}}$ & $72,14 \pm 1,15^{\mathrm{a}}$ & $71,86 \pm 1,12^{\mathrm{a}}$ \\
Persentase hati (\%) & $2,40 \pm 0,04^{\mathrm{a}}$ & $2,34 \pm 0,04^{\mathrm{a}}$ & $2,33 \pm 0,04^{\mathrm{a}}$ \\
Bobot darah (g) & $116,30 \pm 4,48^{\mathrm{a}}$ & $114,25 \pm 4,44^{\mathrm{a}}$ & $106,21 \pm 4,32^{\mathrm{a}}$ \\
Persentase darah (\%) & $3,77 \pm 0,15^{\mathrm{a}}$ & $3,71 \pm 0,14^{\mathrm{a}}$ & $3,43 \pm 0,14^{\mathrm{a}}$ \\
Bobot kepala (g) & $269,13 \pm 4,03^{\mathrm{a}}$ & $272,70 \pm 4,00^{\mathrm{ab}}$ & $285,26 \pm 3,89^{\mathrm{b}}$ \\
Persentase kepala (\%) & $8,71 \pm 0,13^{\mathrm{a}}$ & $8,85 \pm 0,13^{\mathrm{ab}}$ & $9,26 \pm 0,13^{\mathrm{b}}$ \\
Bobot kulit-rambut (g) & $351,85 \pm 4,64^{\mathrm{a}}$ & $356,29 \pm 4,60^{\mathrm{ab}}$ & $369,66 \pm 4,48^{\mathrm{b}}$ \\
Persentase kulit-rambut (\%) & $11,41 \pm 0,14^{\mathrm{a}}$ & $11,55 \pm 0,14^{\mathrm{ab}}$ & $11,99 \pm 0,14^{\mathrm{b}}$ \\
Bobot saluran pencernaan (g) & $445,91 \pm 11.10$ & $454,37 \pm 10,99^{\mathrm{a}}$ & $434,97 \pm 10,71^{\mathrm{a}}$ \\
Persentase saluran pencernaan $(\%)$ & $14,46 \pm 0,38$ & $14,71 \pm 0,38^{\mathrm{a}}$ & $14,03 \pm 0,37^{\mathrm{a}}$ \\
\hline
\end{tabular}

Superskrip yang berbeda pada baris yang sama, beda nyata $(\mathrm{P}<0.05)$; CC: Hyla; PP: Hycole; NN: New Zealand White

Hasil tersebut menunjukkan bahwa adanya pengaruh rumpun terhadap beberapa peubah komponen non-karkas, terutama pada kelinci CC dan NN. Bobot dan persentase kaki depan kelinci CC $(29,73 \pm 0,47 \mathrm{~g}$ dan $0,96 \pm 0,02 \%)$ lebih tinggi dibandingkan dengan kelinci $\mathrm{NN}(27,86 \pm 0,45 \mathrm{~g}$ dan $0,90 \pm 0,01 \%)$. Adapun kelinci $\mathrm{NN}$ memiliki bobot dan persentase kepala $(285,26 \pm 3,89 \mathrm{~g}$ dan $9,26 \pm 0,13 \%)$ serta kulit-rambut $(369,66 \pm 4,48 \mathrm{~g}$ dan $11,99 \pm 0,14 \%)$ yang lebih tinggi dibandingkan dengan kelinci CC $(269,13 \pm 4,03 \mathrm{~g}$ dan $8,71 \pm 0,13 \%$ serta $351,85 \pm 4,64 \mathrm{~g}$ dan $11,41 \pm 0,14 \%$ ). Perbedaan kelinci CC dan NN diduga tidak dipengaruhi oleh bobot potongnya, tetapi dapat disebabkan oleh variasi genetik tiap individu kelinci. Sedangkan kelinci PP memiliki karakteristik komponen non-karkas yang sama dengan kelinci CC maupun NN.

Berdasarkan hasil penelitian Chiericato et al. (1996), persentase bobot kepala dan kulit-rambut kelinci Hyla (CC) berturut-turut adalah 10,55 dan 15,29\%, sedangkan kelinci New Zealand White (NN) adalah 10,69 dan 15,55\%. Hasil tersebut lebih tinggi 
dibandingkan dengan hasil penelitian ini yang dapat disebabkan adanya pengaruh lingkungan dan interaksi genetik dengan lingkungannya seperti perbedaan iklim. Siregar (2014) melaporkan persentase bobot kaki depan kelinci Rex adalah 1,32 $\pm 0,18 \%$. Hasil tersebut lebih rendah dibandingkan dengan hasil penelitian ini dikarenakan perbedaan rumpun. Dewyarsih (2004) menyatakan bahwa perbedaan rumpun berhubungan dengan perbedaan genetik dalam mencapai ukuran dewasa, sehingga persentase bagian-bagian tubuh beberapa rumpun tidak sama. Berat non-karkas sangat mempengaruhi berat karkas, semakin meningkat berat non karkas perolehan karkas yang dihasilkan akan semakin menurun. Hal ini disebabkan jumlah non karkas yang dihasilkan lebih banyak daripada jumlah karkas dari ternak tersebut.

\section{KESIMPULAN}

Kelinci Hyla (CC), Hycole (PP) dan New Zealand White (PP) memiliki bobot potong serta bobot persentase karkas yang sama, namun ada perbedaan pada bagian potongan komersial, serta komponen karkas dan non karkas. Kelinci CC memiliki bobot dan persentase tulang rack dan loin, lemak intermuskular dan ginjal, total lemak serta kaki depan yang lebih tinggi dibandingkan dengan PP dan NN. Kelinci PP memiliki bobot dan persentase tulang hindleg lebih tinggi dibandingkan dengan CC. Sedangkan kelinci NN memiliki bobot dan persentase rack, daging foreleg dan loin, tulang hindleg, kepala dan kulit-rambut lebih tinggi dibandingkan dengan CC dan PP. Produktivitas karkas kelinci $\mathrm{CC}$ dan PP serta NN sangat baik dan dapat dikembangkan lebih lanjut menjadi kelinci pedaging dan/atau melalui tindakan pemuliaan, baik persilangan maupun seleksi menjadi kelinci pedaging yang adaptif iklim tropis.

\section{DAFTAR PUSTAKA}

Baiomy AA, HHM, Hassanien. 2011. Effect of breed and sex on carcass characteristics and meat chemical composition of new zealand white and californian rabbits under upper Egyptian environment. Egypt Poult Sci. 31:275-284.

Basuki PN, Ngadiono, Murdjito G. 1981. Estimasi produksi daging dan organ dalam pada kelinci berdasarkan penentuan bobot hidup. Seminar Fakultas Peternakan. Yogyakarta (Indonesia): Universitas Gadjah Mada.

Blasco A, Ouhayoun J, Masoero G. 1993. Study of rabbit meat and carcass: Criteria and terminology. J Appl Rabbit Res. 15:775-786.

Brahmantiyo B, Raharjo YC. 2009. Karakteristik karkas dan potongan komersial kelinci Rex dan Satin. Laporan Hasil Penelitian. Bogor (Indonesia): Balai Penelitian Ternak.

Brahmantiyo B, Raharjo YC, Martojo H, Mansjeor SS. 2010. Performans produksi kelinci Rex, Satin dan persilangannya. JITV. 15:131-137.

Chiericato GM, Rizzi C, Rostellato V. 1996. Effect of genotype and environmental conditions on the productive and slaughtering performance of growing meat rabbits. Proceedings of the 6th World Rabbit Congress; Toulouse, 3-6 Sept 1996. Toulouse (FR): World Rabbit Science Association. p. 147-15.

De Blass JC, Tores A, Fraga MJ, Perez E, Calves JF. 1977. Influence of weight and age on the body composition of young doe rabbits. J Anim Sci. 45:48-53.

Dewyarsih NT. 2004. Persentase karkas, saluran pencernaan dan organ dalam kelinci jantan lepas sapih dengan substitusi tepung ikan dan bungkil kedelai dalam ransum mengandung ampas teh (Camellia sinensi) [Skripsi]. [Bogor (Indonesia)]: Institut Pertanian Bogor. 
Ditjen PKH. 2015. Kementerian Pertanian RI, sub sektor peternakan [internet]. [diunduh 2016 Juni 13]. Tersedia dari: http://www.pertanian.go.id/ ap_pages/mod/datanak.

Farrell DJ, Raharjo YC. 1984. Potensi ternak kelinci sebagai penghasil daging. Laporan Hasil Penelitian. Bogor (Indonesia): Balai Penelitian Ternak.

Gillespie RJ. 2004. Modern livestock and poultry production. $7^{\text {th }}$ Ed. Connecticut (US): Thomson Learning.

Grimaud. 2012. Manual of hyplus rabbit. $1^{\text {st }}$ Ed. Roussay (France): La Corbiere.

Herman R. 1986. Produksi kelinci (tidak dipublikasikan). Bogor (Indonesia): Institut Pertanian Bogor.

Hernandez JA, Rubio MS. 2001. Effect of breed and sex on rabbit carcass yield and meat quality. World Rabbit Sci. 9:51-56.

Metzger SZ, Odermatt M, Szendro ZS, Mohaupt M, Romvári R, Makai A, Biró-Németh E, Radnai I, Horn P. 2004. Examination on the carcass traits of different rabbit genotypes. Proceeding Puebla (MX): $8^{\text {th }}$ World Rabbit Congress.

Moron OE, Clavero T. 1999. The effect of feeding system on carcass characteristics, non carcass components and retail cut percentages of lambs. Small Rum Res. 34:57-64.

Nizza A, Moniello G. 2000. Meat quality and caecal content characteristics of rabbit according to dietary content and botanical origin of starch. World Rabbit Sci. 8:3-9.

Ouyed A, Brun JM. 2008. Heterosis, direct and maternal additive on rabbit growth and carcass characteristics. 9th World Rabbit Congress, June 10-13.Verona, Italy. p. 195-200.

Ozimba CE, Lukefahr SD. 1991. Evaluation of purebreed and crossbreed rabbits for carcass merit. J Anim Sci. 69:2371-2378.

Parwoto JA. 1995. Pengaruh jenis kelamin dan bobot potong pada karakteristik karkas, flashing indeks, derajat kemontokan tibia dan kadar kolesterol daging kambing jawarandu [Tesis]. [Bogor (Indonesia)]: Institut Pertanian Bogor.

Priyatna N. 2011. Beternak dan bisnis kelinci pedaging. Jakarta (Indonesia): Agro Media Pustaka.

Raharjo YC, Gultom D, Iskandar S, Prasetyo LH. 2001. Peningkatan produktivitas, mutu produk dan nilai ekonomi kelinci eksotis melalui pemuliaan dan nutrisi. Laporan Hasil Penelitian. Proyek Pembinaan Kelembagaan Penelitian dan Pengembangan Pertanian/ARMP-II. Bogor (Indonesia): Balitnak bekerjasama dengan Badan Litbang Pertanian.

Santoso U, Sutarno. 2010. Bobot potong dan karkas kelinci New Zealand White jantan setelah pemberian ransum kacang koro (Mucuna pruriens var. utilis). Bioteknologi. 7:19-26.

Seebeck RM, Tulloh NM. 1968. The representation of yield of dressed carcass. J Anim Prod. 8:281-288.

Siregar GAW. 2014. Pertumbuhan dan produksi karkas kelinci rex pada umur potong yang berbeda [Tesis]. [Bogor (Indonesia)]: Institut Pertanian Bogor.

Soeparno. 1991. Penanganan karkas dan daging. Yogyakarta (Indonesia): Gadjah Mada University Press.

Soeparno. 1992. Ilmu dan teknologi daging. Yogyakarta (Indonesia): Gadjah Mada University Press.

Tahir MA, Al-Jassim AF, Abdullah AHH. 1994. Influence of live weight and cast rasion on distribution of meat. Small Rum Res. 14:219-223.

Wang J, Su Y, Mauricio A, Elzo, Jia X, Chen S, Lai S. 2016. Comparison of carcass and meat quality traits among three rabbit breeds. Korean J Food Sci An. 36:84-89. 
Zita L, Ledvinka Z, Mach K, Kočár J, Klesalová L, Fučíková A, Härtlová H. 2012. The effect of different weaning ages on performance in Hyla rabbits. In: Proceedings $10^{\text {th }}$ World Rabbit Congress; 2012 Sept 3-6. Sharm El Sheikh (Egypt): World Rabbit Science Association. p. 6164.

\section{DISKUSI}

\section{Pertanyaan}

1. Pakan yg diberikan apa saja dan jumlahnya berapa?

2. Lokasi penelitian dimana? Pada abstrak belum ada lokasi.

3. Pengaruh karkas bisa karena pengaruh pakan?

4. Kenapa tidak menggunakan kelinci lokal?

\section{Jawaban}

1. Pakan yg diberikan pelet sebanyak $100 \mathrm{~g}$.

2. Lokasi di Balai Penelitian Ternak, Ciawi Bogor.

3. Kelinci yg digunakan kelinci luar tapi sudah beradaptasi.

4. Kelinci tidak bisa dikategorikan kelinci lokal walaupun sudah adaptasi. 